\title{
Evidence for medieval salt-making by burning Eel-grass (Zostera marina L.) in the Netherlands
}

\section{B. van Geel ${ }^{1}$ \& G.J. Borger ${ }^{2}$}

1 Institute for Biodiversity and Ecosystem Dynamics, Universiteit van Amsterdam, Kruislaan 318, 1098 SM Amsterdam, The Netherlands. Email: vanGeel@science.uva.nl (corresponding author)

2 Amsterdam Research Institute for Global Issues and Development Studies, Universiteit van Amsterdam, Nieuwe Prinsengracht 130, 1018 VZ Amsterdam, The Netherlands. Email: g.j.borger@uva.nl

Manuscript received: June 2004; accepted: March 2005

\begin{abstract}
From the 8th/9th centuries onwards the former peat land area in the northwestern part of the Netherlands was drained and reclaimed. Drainage, peat digging and marine erosion of peat deposits created an extension of shallow marine habitats into which Zostera marina (Eel-grass) expanded. Modern publications do not note the use of Eel-grass as starting material for salt-making. Archaeological evidence, however, indicates salt-making activities by using Zostera in medieval times. We postulate that, after salt-containing peat had become difficult to obtain, Eel-grass was used for salt production.
\end{abstract}

Keywords: Eel-grass, Middle Ages, Netherlands, salt-making, Zostera marina

\section{Introduction}

During the Holocene sea level rise has been the most important control of coastal development in the Netherlands. During the second half of the Holocene the rise of the sea level gradually declined and sedimentation started to dominate erosion (Zagwijn, 1986). The coastline moved in a seaward direction, with deposition of rows of sandy ridges and sand dunes. As a consequence, the hinterland became better protected against marine transgression and peat growth in slightly brackish or fresh water conditions took place. During the Subatlantic period peat deposits were also formed in the northwestern part of the Netherlands (Fig. 1). However, as a consequence of human activities (artificial drainage, reclamation, peat digging) from the 8th/9th centuries onwards, subsidence of peat surfaces took place and consequently the marine influence increased. The former peat bog areas became exposed to inundation during storm surges (van Geel et al., 1983; Borger, 1992). The inhabitants reacted to the recurring floods by creating low dwelling mounds for housing ('terpen'). From the 11th/12th centuries ring-dikes were constructed to protect small areas of cultivated land against the sea (Hallewas, 1984; Schoorl, 1988; Besteman, 1990). However, some peat areas could not be protected and became semi-permanently influenced by brackish or salt water from the sea. During low tides peat digging was possible. The peat could be used for fuel, but due to the high salinity of the peat deposits they also could be burned for salt-making. Drainage and peat digging for fuel and salt-making had considerable consequences for the morphology of the coastal areas in the Netherlands (Vos \& van Heeringen, 1997; Schoorl, 1999) and northwest Germany (Bantelmann, 1967; Marschalleck, 1973). The shallow coastal waters that came into being, were a habitat for Eel-grass (Zostera species). As is known from historical evidence, until the 18th century Eel-grass was used for dike construction and afterwards as filling and packing material. In the second half of the 19th century the area of Eel-grass fields in the Netherlands was estimated to be 6550 ha (van Geel \& Borger, 2002). The construction of the Afsluitdijk (1928-1932) and an outbreak of a Zostera disease in 1932 proved to be very disadvantageous for Eel-grass. 


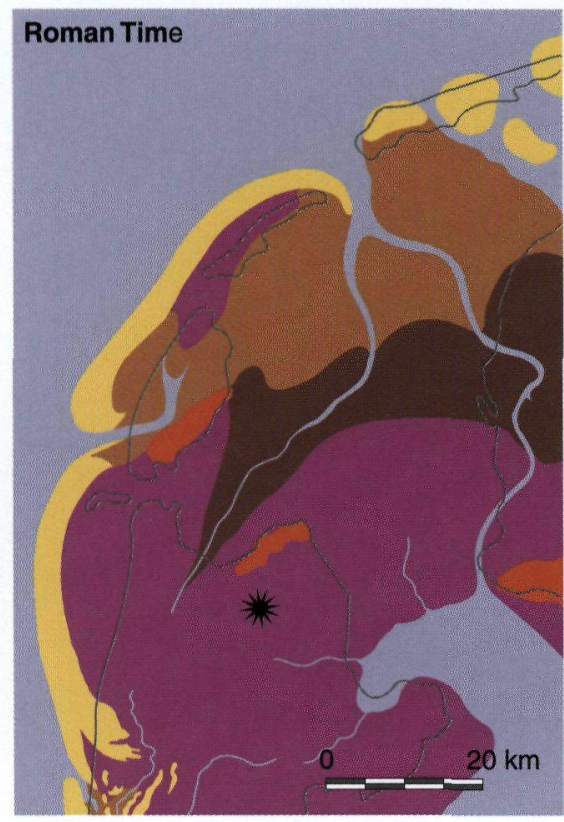

Pleistocene deposits: boulderclay and coversands

Dunes, barrier beaches, sand banks

Older salt marshes and clay deposits (not inundated)

Fig. 1. Development of the coast in northwestern Netherlands from Roman time until ca. 1000 AD (after Schoorl, 1999).

\section{The excavated site near Kolhorn}

During an excavation in 1995 in the Waardpolder (embanked $1844 \mathrm{AD}$ ), situated north of the village of Kolhorn (Fig. 2), two cross sections were made through an isolated, elongated body of in situ peat which was covered by marine deposits. The peat deposit formed the main part of the so-called 'Weg van Paludanus' (Paludanus' road). From the 17th century onwards the origin of this 'road' is under discussion (van Geel \& Borger, 2002). During the excavation subfossil layers of Zostera were found and many ash-filled pits were observed in the peat deposit. Archaeological evidence (mainly pottery sherds) indicates these pits had been dug and were filled up during the 11th and 12th centuries $\mathrm{AD}$ (van der Beek et al., 1996; van der Beek \& Sier, 1996a,b; van Geel \& Borger, 2002). The pit-fills mainly consisted of enormous quantities of grey to orange-coloured ashes. Some of the compact pieces of ash were sampled. After a closer observation of these ash clumps it became evident that the ash contained remains of Eel-grass (van Geel \& Borger, 2002).

\section{Salt-making based by burning peat}

Salt is essential for the preservation of food. In high and late medieval times the province of Zeeland was the region with traditionally the strongest position in the salt industry and salt trade in the Low Countries (Borger, 1992). In that area the medieval process of salt-making is well documented by written

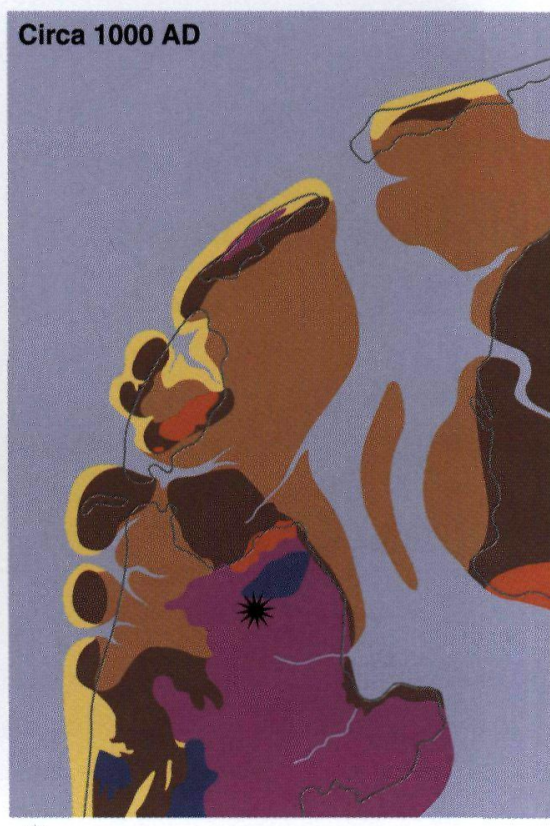

Excavation site

Wadden area

Peat

Lakes

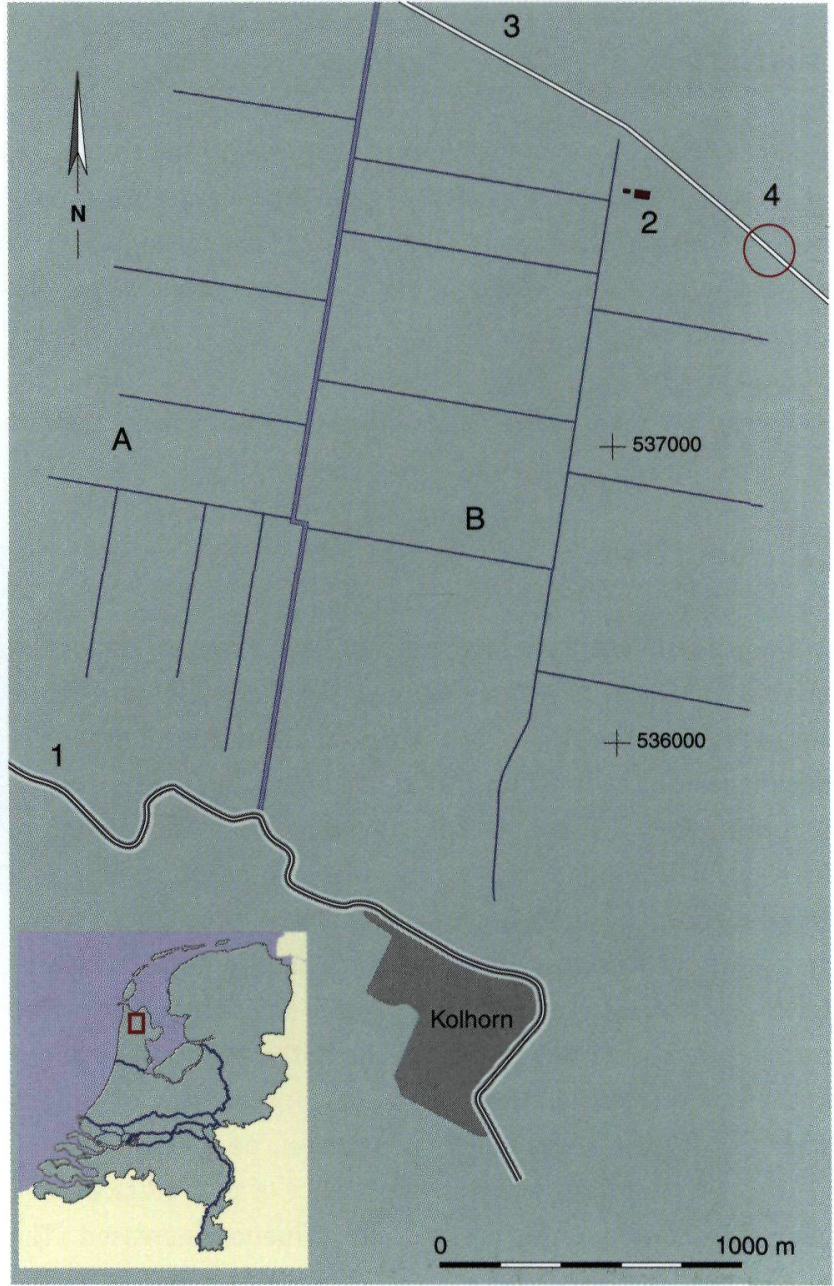

Fig. 2. Location map. A: Wieringerwaard polder; B: Waardpolder; 1: part of Westfrisian ringdike; 2: location farm of landowner; 3: 'Paludanus' road'; 4: excavation site. 


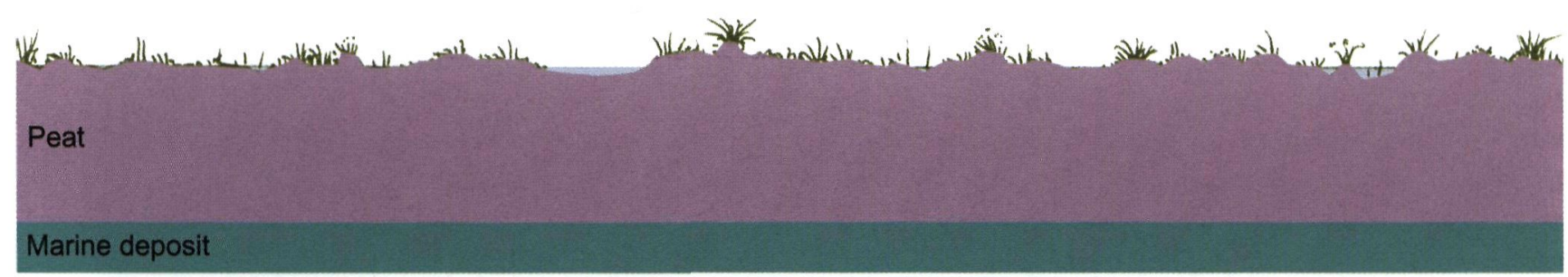

1. Peat formation had taken place on top of marine deposits before the arrival of medieval pioneers (Borger, 1975; van Geel et al., 1983).

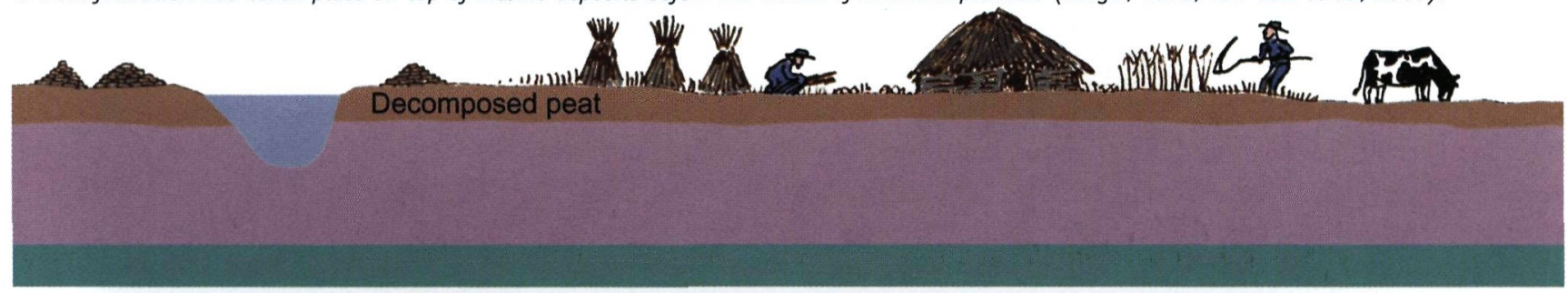

2. Around $1000 \mathrm{AD}$ pioneers reclaimed the peatlands. In the first instance drainage ditches were made. Peat growth stopped and subsidence of the soil surface took place as a consequence of drainage and oxidation. Rye was grown on the oxidised peaty soils and peat digging took place by local farmers. After incidental inundations the area to the south of the excavation site was encircled by dikes (Westfrisian ringdike).

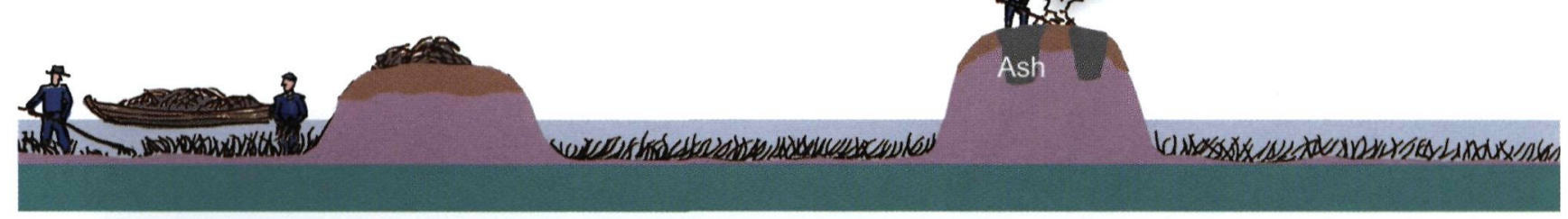

3. The regularly inundated area to the north of the ring dike was lost to agriculture. The peat layers which had been exposed to seawater could be dug and burned for salt production. In areas where the peat had been removed marine sand and clay were deposited. These newly created areas became the habitat for Zostera, which could be collected as an alternative for salt production.

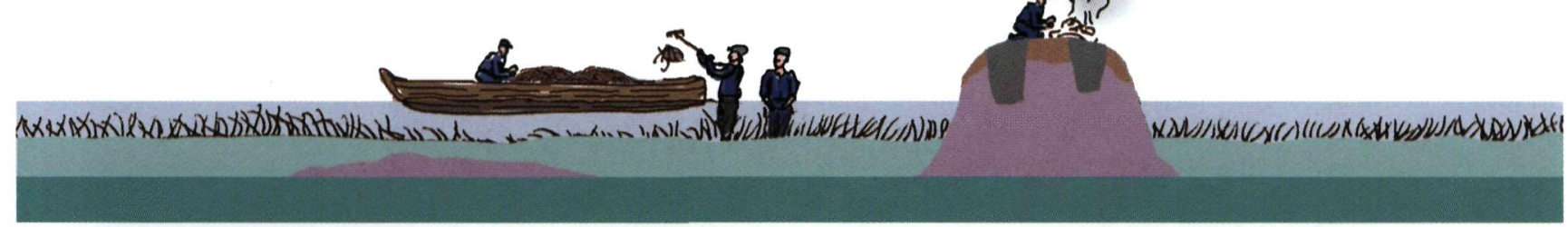

4. An isolated strip of in situ peat ('Paludanus' road') functioned as a production area for salt makers. Peat could be obtained by digging pits, and these pits were filled up with ash produced during the salt-making process.

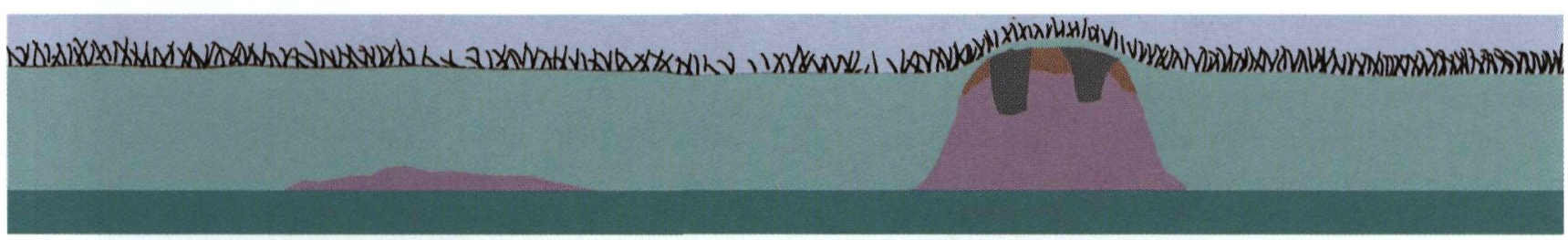

5. As a consequence of continued subsidence of peat deposits and increased marine influence, salt production had to be stopped. The few remaining sites of in situ peat were covered with marine deposits.

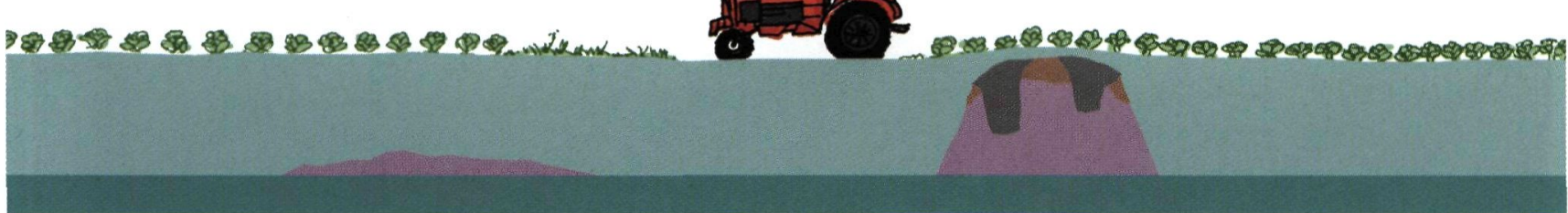

6. The present situation after polder construction: agriculture on marine deposits.

Fig. 3. Reconstruction of development of the landscape as a consequence of human impact and marine influence. 
tradition (van Boxhorn, 1644; Leenders, 2004), pictures (Leenders, 2001) and archaeological evidence (du Burck, 1959; van den Broeke, 1996). From about $300 \mathrm{AD}$ onwards tidal processes started to become increasingly dominant in substantial parts of the former peat landscape of Zeeland (Vos \& van Heeringen, 1997). Large parts of the peat area became brackish and overlain by a thin layer of marine clay.

For the purpose of salt-making, at low tides the clay layer was dug away and the salt-impregnated peat layers were cut into bricks. These were then dried in the wind and burned on the spot. Next, the ashes were gathered and brought to salt sheds (boiling huts), mostly located near towns or villages. In the sheds, the ash was plunged into large drums, preferably filled up with salt water to increase the salt content of the brine, and subsequently heated to evaporate the water. In the province of Zeeland there are no indications that marine algae or Eel-grass have been used for salt production.

In a large area, extending from the northern Netherlands up to Denmark, ample evidence in the landscape indicates extensive extraction of peat. Written references concerning the process of salt making in this area are numerous and date from the eighteenth and nineteenth centuries. Archaeological and geographical evidence well documents industrial salt production in the western coastal area of Schleswig-Holstein (Germany) from the eleventh until the fourteenth century (Bantelmann, 1967; Marschalleck, 1973). Locally, salt-panning continued there until the nineteenth century.

\section{Historical evidence concerning the burning of Zostera for salt-making}

Modern publications do not note the use of Eel-grass as starting material for salt-making. However, archaeological evidence for burning of Zostera marina at a site in the northwestern part of the Netherlands points to salt-making in medieval times. Historical records for salt-making in the coastal areas near the southern border of the North Sea are known from the 18th and 19th centuries. In a translation of a publication by Linnaeus, Houttuyn (1783) described how Eel-grass was still used for producing salt. Houttuyn mentioned that salt also played a role in the production of glass, alum and soap. In his overview of Danish ethnobotanical data, Brøndegaard (1987) mentioned that from medieval times to the 19th century salt production using Zostera was an important home-industry along the coast of Jutland. The Zostera-salt was used for preservation of fish, meat, bacon and butter.

\section{Evidence from the Kolhorn area}

Combining the evidence from historical sources with our observations of remains of Zostera marina in ash lumps, we conclude that the enormous quantities of ash at the excavation site in the Waardpolder near Kolhorn are the result of large-scale salt-making activities. When the salty peat deposits were exhausted and the remaining peat was covered with thick marine deposits, Eel-grass would have become a substitute for salt-making. In the cartoons of Fig. 3 we present our ideas concerning successive phases of human activities and the changing landscape in the excavation area.

\section{Conclusion}

Based on observations during an excavation in the Waardpolder near Kolhorn, we conclude that large-scale medieval burning activities most probably were carried out for salt production. Initially, peat that had been exposed to sea-water was available for this purpose, but afterwards Eel-grass (Zostera marina), that grew in the areas where peat deposits had been removed, was used for salt production. In order to aid future research into the analysis of Zostera in archaeological and geological studies, we illustrate subfossil Zostera marina, in combination with Zostera remains from ashes in plates I and II. 

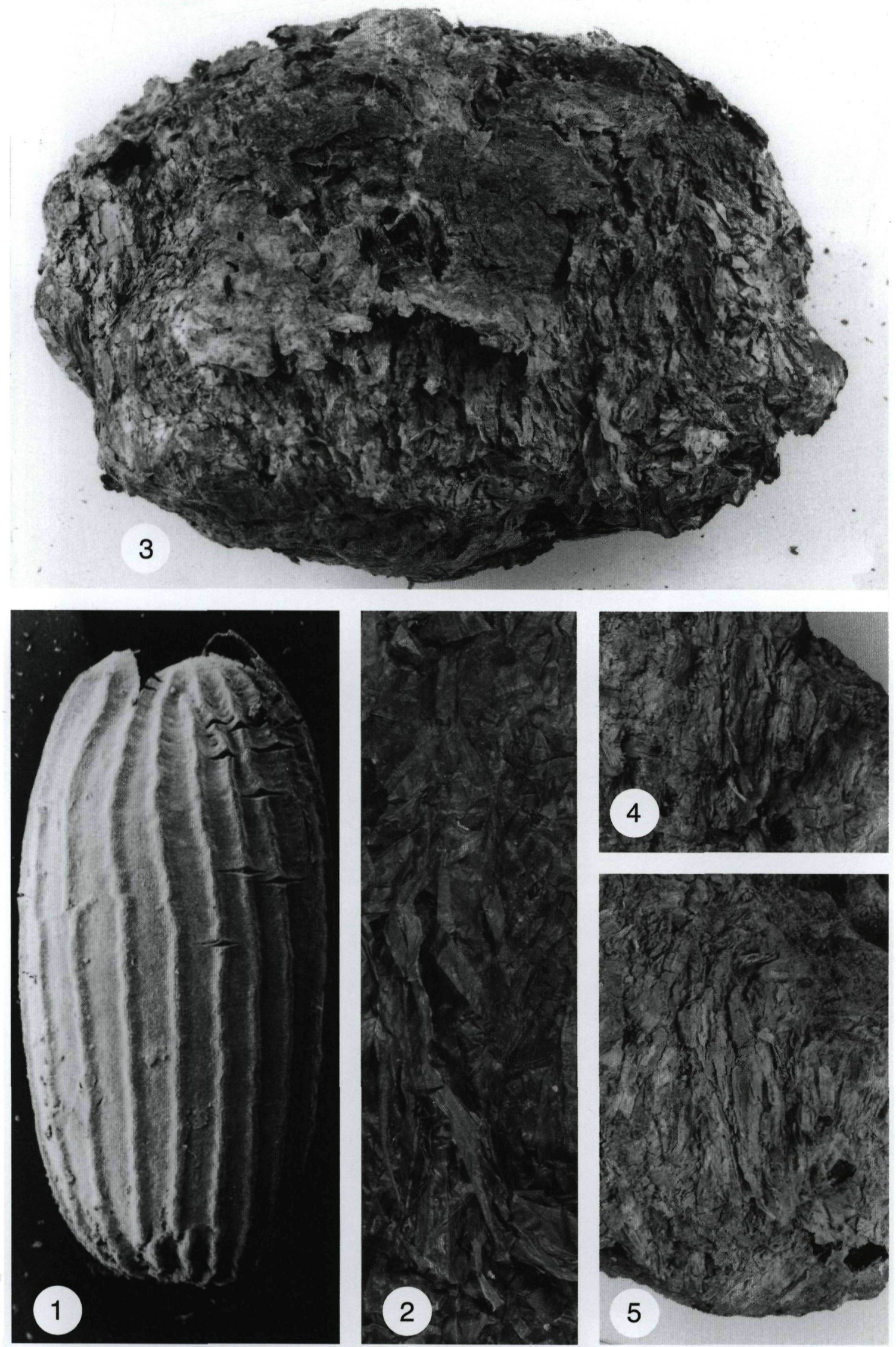

Plate I. Sub-fossil and ashed remains of Eel-grass (Zostera marina) from the excavation site near Kolhorn. 1: seed, found in compact layers of subfossil Eel-grass (x32); 2: yellow-brown subfossil vegetative remains of Eel-grass (x1.6); 3: grey ash-lump with recognizable remains of Eel-grass; 4 and 5: details of grey to light-orange ash lumps with recognizable remains of leaves of Eel-grass. 

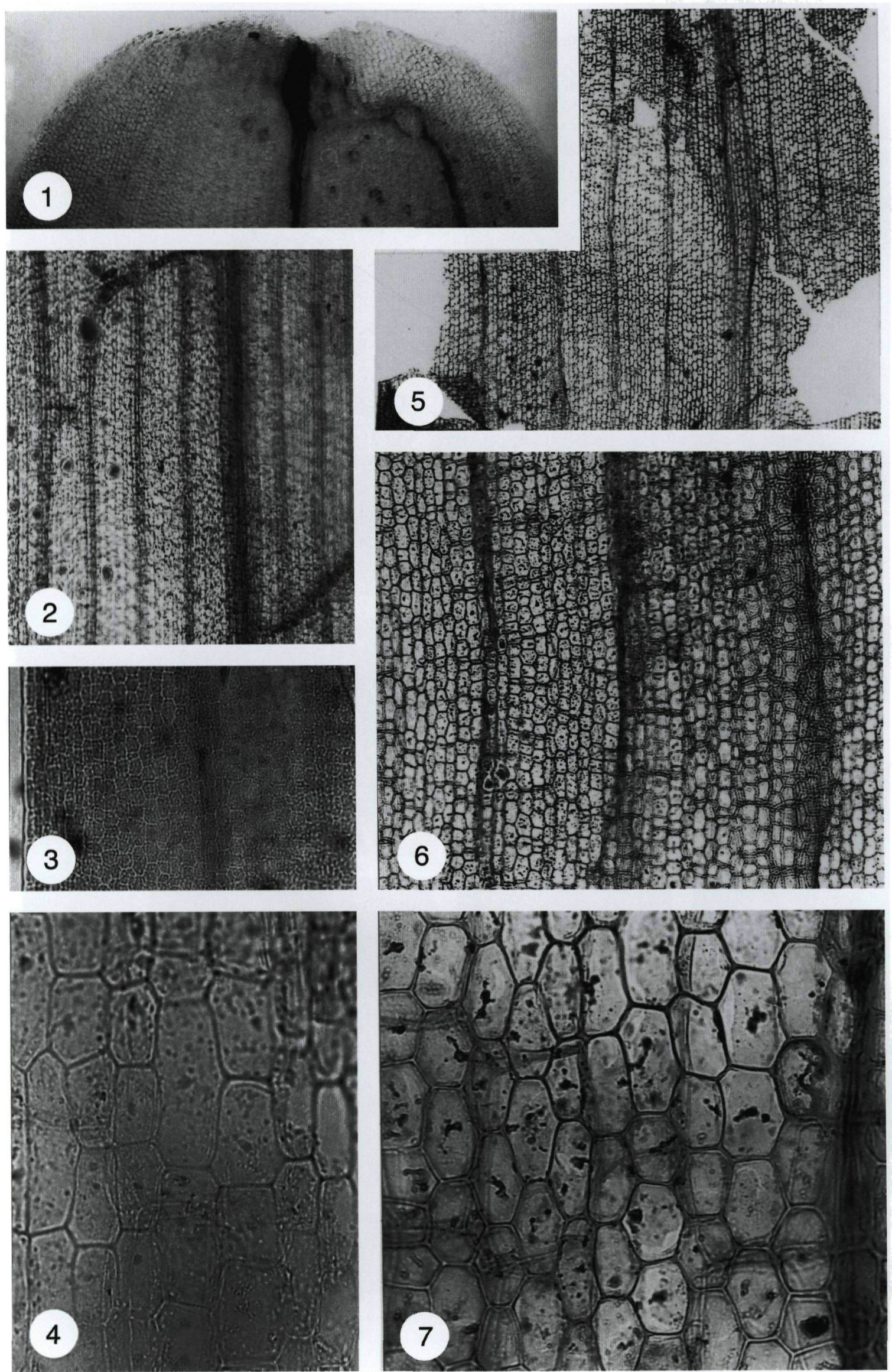

Plate II. Microscopic leaf structures of remains of Eel-grass (Zostera marina) from the excavation site near Kolhorn. 1: subfossil leaftip (x50); 2, 3 and 4: details of subfossil leaves (x50, x125, x500 respectively); 5, 6 and 7: details of ashed leaf remains (x50, x125, and x500 respectively). 


\section{Acknowledgement}

The authors thank Dr Dmitri Mauquoy, Prof.Dr. K.-E. Behre and a second reviewer for valuable remarks.

\section{References}

Bantelmann, A., 1967. Die Landschaftsentwicklung an der schleswigholsteinischen Westküste. Offa Bücher 21, Neumünster: 97 pp.

Besteman, J.C., 1990. North Holland AD 400-1200: turning tide or tide turned? In: J.C. Besteman, J.M. Bos \& H.A. Heidinga (eds): Medieval archaeology in the Netherlands. Studies presented to H.H. van Regteren Altena. Assen: 91 120.

Borger, G.J., 1975. De Veenhoop. Een historisch-geografisch onderzoek naar de verdwijning van het veendek in een deel van West-Friesland. Thesis, University of Amsterdam: $242 \mathrm{pp}$.

Borger, G.J., 1992. Draining-digging-dredging; the creation of a new landscape in the peat areas of the Low Countries. In: J.T.A. Verhoeven (ed): Fens and bogs in the Netherlands: vegetation, history, nutrient dynamics and conservation. Geobotany 18, Dordrecht: 131-171.

Brøndegaard, V.J., 1987. Folk og Flora 1. Dansk etnobotanik, Kobenhavn.

Du Burck, P., 1959. Oudheidkundige vondsten en waarnemingen tijdens een bodemkartering en hun betekenis voor de bewonings- en ontginningsgeschiedenis van de kop van Noord-Holland. Westerheem 8-11/12 (1960): 90-103.

Hallewas, D.P., 1984. Mittelalterliche Seedeiche im holländischen Küstengebiet. Probleme der Küstenforschung im südlichen Nordseegebiet 15: 9-27.

Houttuy, M., 1783. Natuurlyke Historie of Uitvoerige beschryving der Dieren, Planten en Mineraalen, volgens het Samenstel van den Heer Linnaeus. Tweede deel, Veertiende stuk: De Varens, Mossen, enz., Amsterdam.

Leenders, K.A.H.W., 2001. Het schilderij 'Darinkdelven' in het stadsmuseum van Zierikzee. Kroniek van het Land van de zeemeermin (Schouwen-Duiveland) 26: 21-34.

Leenders, K.A.H.W., 2004. The start of peat digging for salt production in the Zeeland region. In: M. Lodewijckx (ed): Bruc ealles well. Archaeological essays concerning the peoples of North-West Europe in the first millennium AD. Leuven: 107-110.
Marschalleck, K.H., 1973. Die Salzgewinnung an der friesischen Nordseeküste. Probleme der Küstenforschung im südlichen Nordseegebiet 10: 127-150.

Schoorl, H., 1988. Archeologische kaart van Nederland 1:100.000. Blad Hollands Noorderkwartier ca. 1350 na Chr. Bewoning en dijken, Amersfoort/Alkmaar.

Schoorl, H., 1999. De convexe kustboog. Texel-Vlieland-Terschelling. Bijdragen tot de kennis van het westelijk Waddengebied en de eilanden Texel, Vlieland en Terschelling. Deel 1: Het westelijk Waddengebied en het eiland Texel tot circa 1550. Schoorl: $187 \mathrm{pp}$.

Van Boxhorn, M.Z., 1644. Chroniick van Zeelandt, eertijds beschreven door d'Heer Johan Reygersbergen, nu verbetert ende vermeerdert, Middelburg.

Van den Broeke, P.W., 1996. Turfwinning en zoutwinning langs de Noordzeekust. Een verbond sinds de IJzertijd? Tijdschrift voor Waterstaatsgeschiedenis 5: 48-59.

Van der Beek, H.S.M., Burnier, Y. \& van Duinen, A., 1996. Anna Paulowna: Kolhorn, Waardpolder 2. In: J.-K.A. Hagers, Archeologische kroniek van Noord-Holland over 1995. Holland 28: 315-316.

Van der Beek, H.S.M. \& Sier, M.M., 1996a. Aanvullend archeologisch onderzoek op twee locaties binnen het plangebied 'Windturbinepark Waardpolder' (Noord-Holland), Rapportages Archeologische Monumentenzorg 3, Amersfoort.

Van der Beek, H.S.M. \& Sier, M.M., 1996b. Anna-Paulowna: Kolhorn-Waardpolder 1. In: J.-K.A. Hagers, Archeologische kroniek van Noord-Holland over 1995. Holland 28: 314-315.

Van Geel, B. \& Borger, G.J., 2002. Sporen van grootschalige zoutwinning in de Kop van Noord-Holland. Westerheem 52: 242-260.

Van Geel, B., Hallewas, D.P. \& Pals, J.P., 1983. A Late Holocene deposit under the Westfriese Zeedijk near Enkhuizen (Prov. of $\mathrm{N}$-Holland, The Netherlands): palaeoecological and archaeological aspects. Review of Palaeobotany and Palynology 38: 269-335.

Vos, P.C., \& van Heeringen, R.M., 1997. Holocene geology and occupation history of the Province of Zeeland. In: M.M. Fischer (ed): Holocene evolution of Zeeland (SW Netherlands), Haarlem: 5-109.

Zagwijn, W.H., 1986. Nederland in het Holoceen, 's-Gravenhage: 46 pp. 